ISSN: 1641-4713; e-ISSN: 2081-1160

DOI: https://doi.org/10.36551/2081-1160.2019.24.1-5

\title{
Critical Approaches to Food Heritage in Latin America. Introduction
}

Enfoque crítico del patrimonio alimentario en América Latina: Introducción

\author{
Ronda L. Brulotte \\ Department of Geography \& Environmental Studies \\ University of New Mexico, USA \\ ID ORCID: https://orcid.org/0000-0002-3025-2087 \\ E-mail: brulotte@unm.edu \\ Renata E. Hryciuk \\ Institute of Ethnology and Cultural Anthropology \\ University of Warsaw, Poland \\ ID ORCID: https://orcid.org/0000-0002-6740-0514 \\ E-mail: r.hryciuk@uw.edu.pl
}

We are pleased to present this special issue of Revista del CESLA: International Latin American Studies Review, "Critical Approaches to Food Heritage in Latin America." It features contributions from an international group of sociocultural anthropologists and other food scholars who examine the ways in which food and food-related practices are constructed as food heritage or patrimony in Mexico as well as selected regions of Latin America. The focus on Mexico is not coincidental: it was one of the first countries, in 2010, to secure a UNESCO Intangible Cultural Heritage (ICH) designation for its cuisine and has served as a model for other countries seeking UNESCO recognition. Ratified as "Traditional Mexican Cuisine-ancestral, ongoing community culture, the Michoacán paradigm," Mexico's UNESCO bid revealed not only a nationalist agenda for raising global awareness about its gastronomy but also for promoting tourism among other developmental programs. ${ }^{1}$ The intervening decade has witnessed the acceleration of the heritagization of Mexican cuisine at multiple scales. But this

\footnotetext{
${ }^{1}$ See https://ich.unesco.org/en/RL/traditional-mexican-cuisine-ancestral-ongoing community-culture-the-michoacan-paradigm-00400, accessed 23 December 2019.
} 
trend is not limited to Mexico, as the authors here demonstrate using case studies from Bolivia, Cuba, and Peru. Throughout the Americas there has been a proliferation of both public and private initiatives aimed at "safeguarding" regional and national foods and their associated culinary knowledge, often accompanied by aggressive marketing.

At the same time, seminal scholarship on cultural heritage has dismantled the idea that heritage is simply objects or practices held over from the past (Hall 1999, Kirshenblatt-Gimblett 1995); this includes particular foodstuffs, preparations, and culinary knowledge (Brulotte and Di Giovine 2014, Geyzen 2015). All of the articles in this volume thus begin from the proposition that food heritage is best understood as an ongoing process characterized by both material and discursive dimensions. The authors directly or indirectly explore fundamentally shared meanings of food that position particular goods (e.g. sugar in Cuba and corn in Mexico), social actors (e.g. female "traditional cooks" in Mexico), and activities (e.g. organizing food festivals, fine dining) within frameworks of culinary or food heritage.

The opening essay by Charles-Édouard de Suremain, "From Multi-Sited Ethnography to Food Heritage", puts the well-established methodological tool of multi-sited ethnography to test in relation to food heritage. By focusing on examples from Bolivia and Mexico, de Suremain highlights the tensions between "institutionalized heritage" and "ordinary heritage". He discusses the advantages and limitations of the multi-sited approach, and its implications for ethnographic work on food heritage. He then emphasizes the conditions of its implementation by returning to the ways in which they differ from the comparative approach characterized as transnationalization and "glocal" analysis. He also suggests some theoretical and methodological avenues for further research in the critical anthropology of food heritagization.

In the next article, "Patrimonios a la carta: una aproximación al patrimonio alimentario desde cuatro restaurantes en Lima", Raúl Matta and Charles-Édouard de Suremain use four restaurants of varying types and status in the city of Lima to analyze heritage cuisines from the perspective of those who sustain and promote them on a daily basis. They examine how chefs, cooks, and restaurateurs propose and perform "ordinary" versions of food heritage and how these emerge from representations, values, and hierarchies related to their individual histories and life projects. They show how these cuisines provide a view of food heritage as much more entrenched within day-to-day and future challenges than in past and predetermined conceptions of culture. 
In her text "Body Image and the Ambivalence of Sugar as Heritage Among Cuban Dancers" Ruxandra Ana focuses on vernacular understandings of sugar as Cuban heritage in light of ongoing processes of westernization of Cuban foodways and body image. Based on several years of ethnographic fieldwork conducted among female dancers in Havana's private schools, this article demonstrates people's experiences of and beliefs about heritage. She focuses on changes in local, often ambivalent, understandings of sugar as heritage, which may include even stigmatization stemming from newly emerging canons and ideals governing body image.

The next essay "La Alquimista de los Sabores: Gastronomic heritage, gender, and the tourist imaginary in Mexico" is based on multi-sited fieldwork carried out in central Oaxaca and an analysis of secondary sources. Anthropologist Renata E. Hryciuk looks at the rise of a culinary celebrity, Zapotec cook Abigail Mendoza Ruíz of Teotitlán del Valle, Oaxaca, in the broader context of a Mexican cultural politics of food heritage. Focusing on food-related biography, this essay reveals the vernacular dynamics of heritagization of native foodways and the role renowned female cooks (cocineras) have played in this process. Hryciuk focuses on negotiations and contestations as well as open conflicts related to the representation of heritage; this includes the politics and rights between different actors engaged over the years in (re)constructing a social imagery of ethnic female cooking for the benefits of the tourism industry and, more broadly, state attempts at re-branding Mexico as a safe gastronomic destination.

The final article in this volume, "Género y Cultura de Maíz: en la lucha por definir otra soberanía alimentaria" by Ivonne Vizcarra Bordi, is based on six years of ethnographic research with Mazahua peoples of the State of Mexico. It scrutinizes the cross-cultural relationships of what the Mexico's "Maize Culture" through a decolonial methodology based on what the author terms "states of consciousness". She claims that this method allows for the construction of a decolonial critical mass capable of confronting the capitalist-patriarchal binomial that imposes certain power relations and directs global agro-industrial food policies; she believes that this is a critical step in reversing the increasing trend toward low-quality diets and the loss of biosafety in rural localities. The text analyses four states of consciousness among Mazahua women (pre-conscience, collective, rational, and liberating). She argues for the liberatory potential of the accumulated knowledge and experiences of indigenous peasant women who sustain Maize Culture, which she sees as a site for a new type of sovereignty and ethic of life based on the harmony of human and non-human beings. 
This special issue concludes with two book reviews. In "Sobre la íntima relación entre las mujeres y el maíz", Charlynne Curiel reviews a collection of essays edited by Mexican anthropologist Ivonne Vizcarra Bordi, published in 2018 by the Universidad Autónoma del Estado de México. The collection, "Volteando la tortilla: genéro y maíz en la alimentación actual en México", comprises an array of ethnographic research carried out by Mexican feminist scholars on gendered aspects of the (de)heritagization of corn in contemporary Mexico. Employing diverse, gendered experiences and perspectives relating to corn, the volume contributors pose the question of whether it is possible to build a critical mass to safeguard the basic staple food of a Mesoamerican "heritage diet".

The second book reviewed by Ronda L. Brulotte deals with the neoliberal reconstruction of Mexican foodways and its health consequences in Mexico as a result of the North American Free Trade Agreement. Published in 2018, "Eating NAFTA: Trade, Food Policies, and the Destruction of Mexico" by medical anthropologist Alyshia Gálvez analyzes the paradox of the globalization of Mexican cuisine: heritage-making for the benefit of the food tourism industry that have brought benefits to a privileged few, while the rise of industrial farming and food processing have exacerbated chronic diseases among a growing majority of Mexicans.

Taken as a whole, the contributions to the issue point to the latest sites of exploration and debates taking place at the intersection of critical heritage and food studies. Earlier scholarship focused on conceptualizing food heritage-and heritage generally, both tangible and intangible — as process, rather than an object in need of protection or conservation. Critically, this latter orientation still holds traction within multiple sectors throughout Latin America, who rely on a reified food heritage as a means to specific economic, political, and/or social ends. In this sense, the debates are far from over. Yet what the authors here demonstrate is how food scholars within the social sciences are experimenting with new methodological and theoretical framings that allow for a deeper, more nuanced understanding of how processes of heritagization work on the ground, while also expanding the range of actors, practices, and materials we associate with the coproduction of food heritage. What the bodies of Cuban dancers, urban restaurant chefs in Lima, and rural female cooks in Mexico all illuminate is an increasing consciousness among individuals and social groups themselves of the power of cultural heritage as a productive force; no longer the province of formal institutions, the tourism industry, or even scholars themselves, the concept of "food heritage" is becoming globally legible and utilized as a means of self-fashioning and cultural production by a wide range of social actors. 


\section{WORKS CITED}

Brulotte, R. L., Di Giovine M. A. (2014). Edible Identities: Food as Cultural Heritage. New York, NY: Routledge.

Geyzen, A. (2015). Food Studies and the Heritage Turn: A Conceptual Repertoire. Food and History, 2(12), pp. 67-96. https://doi.org/10.1484/J.FOOD.5.108963.

Hall, S. (1999). Whose Heritage? Un-settling 'The Heritage', Re-imaging the Post-nation. Third Text, (13), pp. 3-13. https://www.tandfonline.com/doi/abs/10.1080/09528829908576818

Kirshenblatt-Gimblett, B. (1995). Theorizing Heritage. Ethnomusicology, 3(39), pp. 367-380. https://doi.org/10.2307/924627 
